Crop Breeding and Applied Biotechnology 15: 146-153, 2015

Brazilian Society of Plant Breeding. Printed in Brazil

\title{
ARTICLE
}

http://dx.doi.org/10.1590/1984-70332015v15n3a26

\section{Genetic base of Brazilian irrigated rice cultivars}

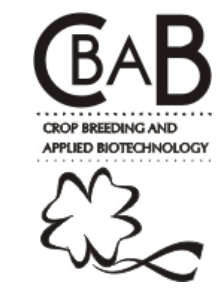

Hudson de Oliveira Rabelo ${ }^{1 *}$, João Filipi Rodrigues Guimarães ${ }^{2}$, José Baldin Pinheiro ${ }^{3}$ and Edson Ferreira da Silva ${ }^{4}$

Received 02 June 2014

Accepted 16 March 2015

\begin{abstract}
The aim of this study was to estimate the genetic base of Brazilian irrigated rice cultivars released in the period from 1965 to 2012. The genealogies of the cultivars were obtained based on information from marketing folders, websites, crossings records, and scientific articles. The following factors were calculated: relative genetic contribution (RGC), accumulated genetic contribution (AGC), frequency (in percentage) of each ancestor in the genealogy (FAG), number of ancestors that constitute each cultivar (NAC), number of ancestors responsible for 60\%,70\%,80\% and 90\% of the genetic base (NAGB), and average number of ancestor per cultivar (ANAC). The cultivars were also grouped based on the period of release (1965-1980, 1981-1990, 1991-2000 and 2001-2012). For each grouping, the previously described factors were also estimated. A total of 110 cultivars were studied and it was concluded that the genetic base of Brazilian irrigated rice cultivars is narrow.
\end{abstract}

Key words: Oryza sativa, relative genetic contribution, accumulated genetic contribution, genealogies, genetic vulnerability.

\section{INTRODUCTION}

Rice is considered to be the cereal crop of greatest socioeconomic importance since it is one of the staple food components and the main dietary energy source for the human population. Brazil is the eighth largest producer of this grain, and Brazilian production in the 2010/2011 crop season was estimated at 9.45 million tons (CEPA 2011). The high productivity rates obtained in the country are mostly due to the activity of research institutes, mainly through development of new cultivars and crop techniques.

The first rice genetic breeding activities in Brazil began in 1936, at the Instituto Agronômico de Campinas (IAC), when the first competitive tests were carried out. After that, in 1938, the first hybridizations were carried out between varieties introduced from other countries and local breeds (Viegas et al. 1945). In the same year, the Instituto Rio Grandense de Arroz (IRGA) began its irrigated rice breeding program (Soares et al. 2004a). Up to the 1970s, rice breeding in Brazil was carried out basically through the activities of IAC and IRGA. As of 1970, other programs were established at federal and state level. The development of domestic cultivars spurred Brazilian rice growing, making it competitive and profitable in view of yield increases in the order of $30 \%$ registered in the middle of the 1980 s (Morais and Rangel 1997).

The Brazilian irrigated rice cultivars were developed from lines and cultivars coming from international research institutes, such as the International Rice Research Institute (IRRI) in the Philippines (Morais et al. 2004), the International Center for Tropical Agriculture (CIAT), and the Institute for Research in Tropical Agriculture (IRAT), currently called the Centre de Coopération Internationale en Recherche Agronomique pour le Développement (CIRAD), headquartered in France. These genotypes were introduced in Brazil by domestic breeding programs, and they represent most of the genetic base of Brazilian irrigated rice cultivars. The genetic base is defined by Cui et al. (2000) as the entire set of genes that contribute toward the development of cultivars of a determined species.

Since they originate from a restricted group of ancestors, from crosses with kinship relations, and for having been developed by breeding methods that do not allow broad recombination, such as genealogical, populational and backcrossing methods (Cordeiro 2008), Brazilian cultivars

\footnotetext{
${ }^{1}$ Universidade Federal Rural de Pernambuco (UFRPE), Departamento de Agronomia, Rua Dom Manoel de Medeiros, s/n, 52.171-900, Recife, PE, Brazil. *E-mail: hudsonorabelo@gmail.com

${ }^{2}$ Universidade Federal de Viçosa (UFV), Departamento de Biologia Geral, Av. P.H. Rolfs, s/n, 36.571-900, Viçosa, MG, Brazil

${ }^{3}$ Escola Superior de Agricultura Luiz de Queiroz (ESALQ), Departamento de Genética, Av. Pádua Dias, 11, 13.418-900, Piracicaba, SP, Brazil

${ }^{4}$ UFRPE, Departamento de Biologia
} 
have a narrow genetic base (Rangel et al. 1996).

Narrowing of the genetic base is considered one of the main drawbacks of modern agriculture since it causes genetic vulnerability of cultivars to biotic and abiotic stresses, which may result in yield reduction in the rice crop (Rangel et al. 1996). For genetic breeding purposes, narrow genetic base results in low variability, which may limit possibilities for recombination and genetic segregation, and hinder achievement of gains from selection. Knowledge regarding the magnitude of the genetic base of Brazilian irrigated rice cultivars may help in the choice of divergent parents in breeding programs, contributing to the broadening of the genetic base of cultivars and cultivated species.

In order to provide assistance to genetic breeding programs, the aim of this study was to estimate the genetic base of Brazilian irrigated rice cultivars released in the commercial market in Brazil in the period from 1965 to 2012, except for the cultivars developed by private companies, since their genealogical records are not disclosed.

\section{MATERIAL AND METHODS}

Irrigated rice cultivars released for commercial use in the period from 1965 to 2012 were studied. The purpose was to construct the genealogy of each cultivar for the identification of divergent ancestors. During the preparation of the genealogies, it was considered information obtained from marketing folders of varieties, websites, genealogical records of research institutes, such as the IRRI $(1985,1998)$ and CIAT (2005), and scientific articles (Dilday 1990, Rangel et al. 1996, Montalván et al. 1998, Silva et al. 1999, Châteal and Guimarães 2002, Cutrim and Rangel 2002, Soares

Table 1. Relative genetic contribution (RGC\%), accumulated genetic contribution (AGC\%) and frequency of the ancestors in the genealogy (FAG\%) of Brazilian cultivars of rice released on the commercial market in the period from 1965 to 2012

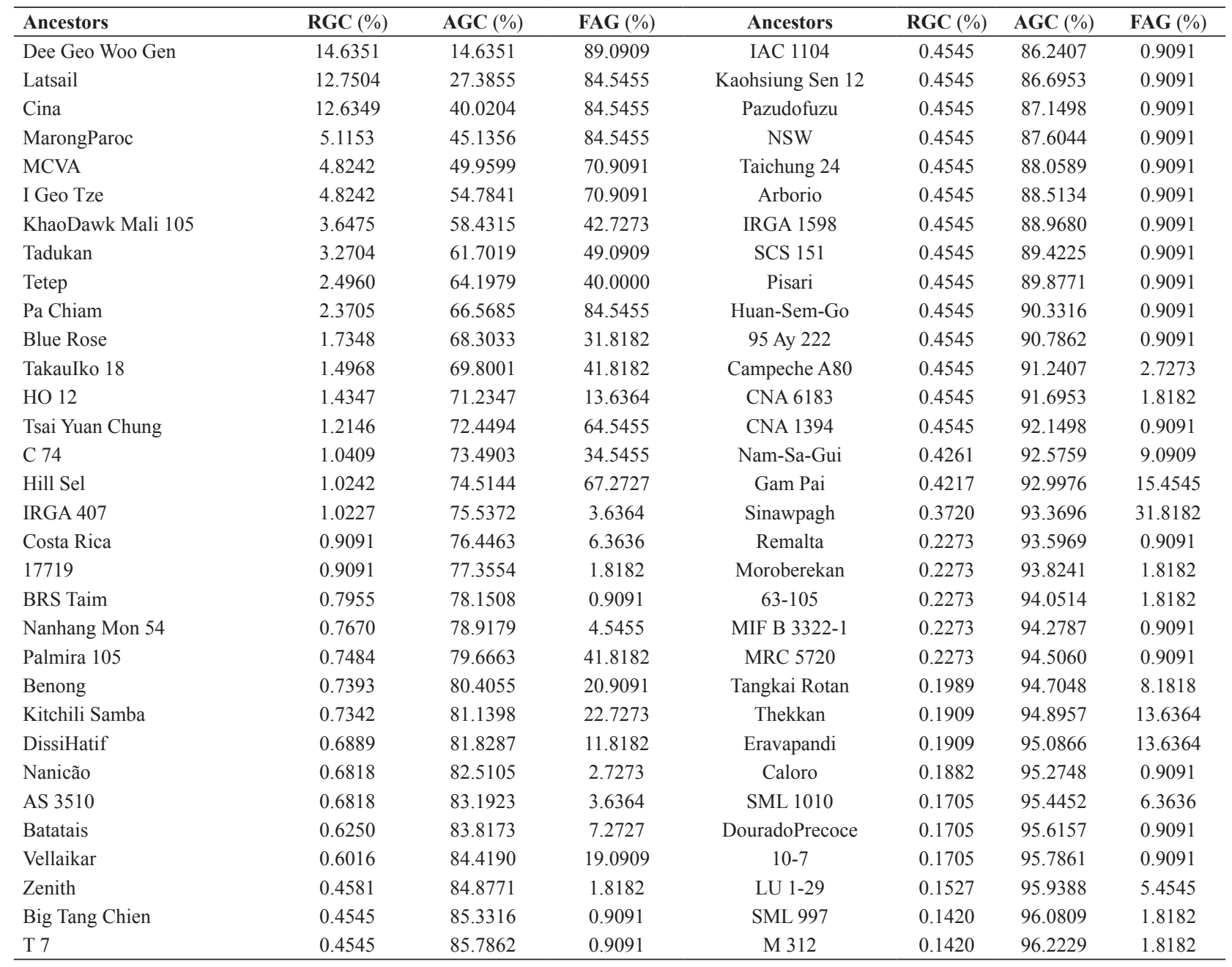


et al. 2005, Rangel et al. 2007, Cordeiro and Medeiros 2010a). Hybrid cultivars and a large part of the cultivars developed by private companies were not evaluated since their genealogical records are not disclosed.

The relative genetic contribution (RGC) of each ancestor was estimated considering that there is no degree of kinship between the ancestors, and that the theoretical proportion of genes transferred from a parent to its offspring is $50 \%$ (Delannay et al. 1983). This is estimated from the sum of the individual contributions of each ancestor in all the cultivars, according to the methodology used by Rangel et al. (1996), Montalván et al. (1998) and Silva et al. (1999). The ancestors were classified in decreasing order of the RGC values, and the Accumulated Genetic Contribution (AGC) was estimated from the successive sum of the RGC of each ancestor.

The frequency (in percentage) of each ancestor in the genealogy (FAG) was estimated considering the number of cultivars that had a certain ancestor in their genealogy in relation to the total number of cultivars analyzed. For each cultivar, it was estimated the number of ancestors that constitute them (NAC).

The cultivars were also grouped according to the year of commercial release, establishing four periods delimited by the years 1965-1980, 1981-1990, 1991-2000 and 2001-2012. For each grouping it was determined: number of ancestors responsible for $60 \%, 70 \%, 80 \%$ and $90 \%$ of the genetic base (NAGB), number of ancestors and cultivar (NA and $\mathrm{NC}$, respectively), ratio between the number of ancestors and number of cultivars (NA/NC), and average number of ancestors per cultivar (ANAC). The latter corresponds to the sum of each NAC divided by the total number of cultivars.

\section{RESULTS AND DISCUSSION}

The genealogical information from 110 Brazilian irrigated rice cultivars was obtained, which were developed from 123 different ancestors (Table 1). The cultivars IAC 600, IAS 12-9 Formosa and BR 3 Caeté were not included

\begin{tabular}{|c|c|c|c|c|c|c|c|}
\hline Ancestors & RGC (\%) & AGC (\%) & FAG (\%) & Ancestors & RGC (\%) & AGC (\%) & FAG $(\%)$ \\
\hline Unknown & 0.1326 & 96.3555 & 19.0909 & Palgweng & 0.0568 & 99.3001 & 1.8182 \\
\hline Oryza nivara & 0.1324 & 96.4879 & 16.3636 & FB 24 & 0.0568 & 99.3569 & 0.9091 \\
\hline Venezuela 503 & 0.1232 & 96.6111 & 14.5455 & Lung Shengi & 0.0568 & 99.4137 & 0.9091 \\
\hline Bayang & 0.1155 & 96.7266 & 27.2727 & $63-104$ & 0.0568 & 99.4706 & 0.9091 \\
\hline Hayayuki & 0.1136 & 96.8403 & 0.9091 & Tox 1525 & 0.0568 & 99.5274 & 0.9091 \\
\hline Asominori & 0.1136 & 96.9539 & 1.8182 & Tox 939 & 0.0568 & 99.5842 & 0.9091 \\
\hline Matão & 0.1136 & 97.2948 & 0.9091 & B $589 \mathrm{~A}$ & 0.0393 & 99.7265 & 9.0909 \\
\hline Pérola & 0.1136 & 97.4084 & 0.9091 & 419 C-57 & 0.0284 & 99.7549 & 6.3636 \\
\hline Jaguari & 0.1136 & 97.5221 & 0.9091 & Della - X2 & 0.0284 & 99.7833 & 0.9091 \\
\hline Yola & 0.1136 & 97.6357 & 0.9091 & SeraupaBesar 15 & 0.0262 & 99.8095 & 11.8182 \\
\hline Lambayeque Mo1 & 0.1136 & 97.7494 & 0.9091 & Kameji & 0.0213 & 99.8308 & 1.8182 \\
\hline Agostano & 0.1136 & 98.2039 & 0.9091 & Joshyu & 0.0142 & 99.8988 & 0.9091 \\
\hline Cesariot & 0.1136 & 98.3175 & 0.9091 & Pankari 203 & 0.0142 & 99.9130 & 0.9091 \\
\hline Oro & 0.1136 & 98.4312 & 0.9091 & $283 \mathrm{~A} 7$ & 0.0142 & 99.9272 & 1.8182 \\
\hline Jojutla & 0.0959 & 98.5271 & 3.6364 & Smooth 4 & 0.0142 & 99.9414 & 0.9091 \\
\hline Mudgo & 0.0852 & 98.6123 & 1.8182 & Aikoku & 0.0107 & 99.9521 & 1.8182 \\
\hline Makalioka & 0.0852 & 98.6975 & 1.8182 & Colusa & 0.0071 & 99.9592 & 0.9091 \\
\hline Variety From Zaire & 0.0852 & 98.7827 & 0.9091 & Shoemed & 0.0071 & 99.9663 & 0.9091 \\
\hline 560 & 0.0852 & 98.8680 & 0.9091 & OS 6 & 0.0071 & 99.9734 & 0.9091 \\
\hline S $12-30$ & 0.0710 & 98.9390 & 1.8182 & D $85-42$ & 0.0071 & 99.9805 & 0.9091 \\
\hline Lady Wright & 0.0675 & 99.0065 & 0.9091 & Machique & 0.0071 & 99.9876 & 0.9091 \\
\hline
\end{tabular}


in the evaluations since they were derived from direct selection of the ancestors Wang Xue Ren, Kashiung 21 and Pisari, respectively. Fourteen cultivars produced by private companies were not considered due to the lack of genealogical information. The relative genetic contributions (RGC) ranged from 0.0018 to $14.6351 \%$. The highest values are in reference to the ancestors Dee Gee Woo Gen, Latisail and Cina, which contributed to approximately $40 \%$ of the genes of the 110 cultivars, with RGC of $14.6351,12.7504$ and $12.6349 \%$, respectively (Table 1 ).

The average number of ancestors per cultivar (ANAC) was 14.37, with values ranging from 2 to 41 (Table 2). Cultivars Bluebonnet, Bluebonnet 50 and BRS Sinuelo CL presented the lowest number of ancestors per cultivar (NAC $=$ 2); Bluebonnet and Bluebonnet 50 are derived from the crossing between Rexoro and Fortuna cultivars. BRS Sinuelo CL was obtained by three cycles of backcrossing between BRS7 Taim and the genotype AS 3510; the latter contains a gene, which confers tolerance to imidazolinone-based herbicides used mainly for red rice control in commercial crops (Magalhães Júnior et al. 2010). Nevertheless, since the parents of BRS 7 Taim are not known, it is possible that BRS Sinuelo CL has a broader genetic base than it has

Table 2. Number of ancestors per cultivar (NAC) of 110 Brazilian irrigated rice cultivars released on the commercial market in the period from 1965 to 2012

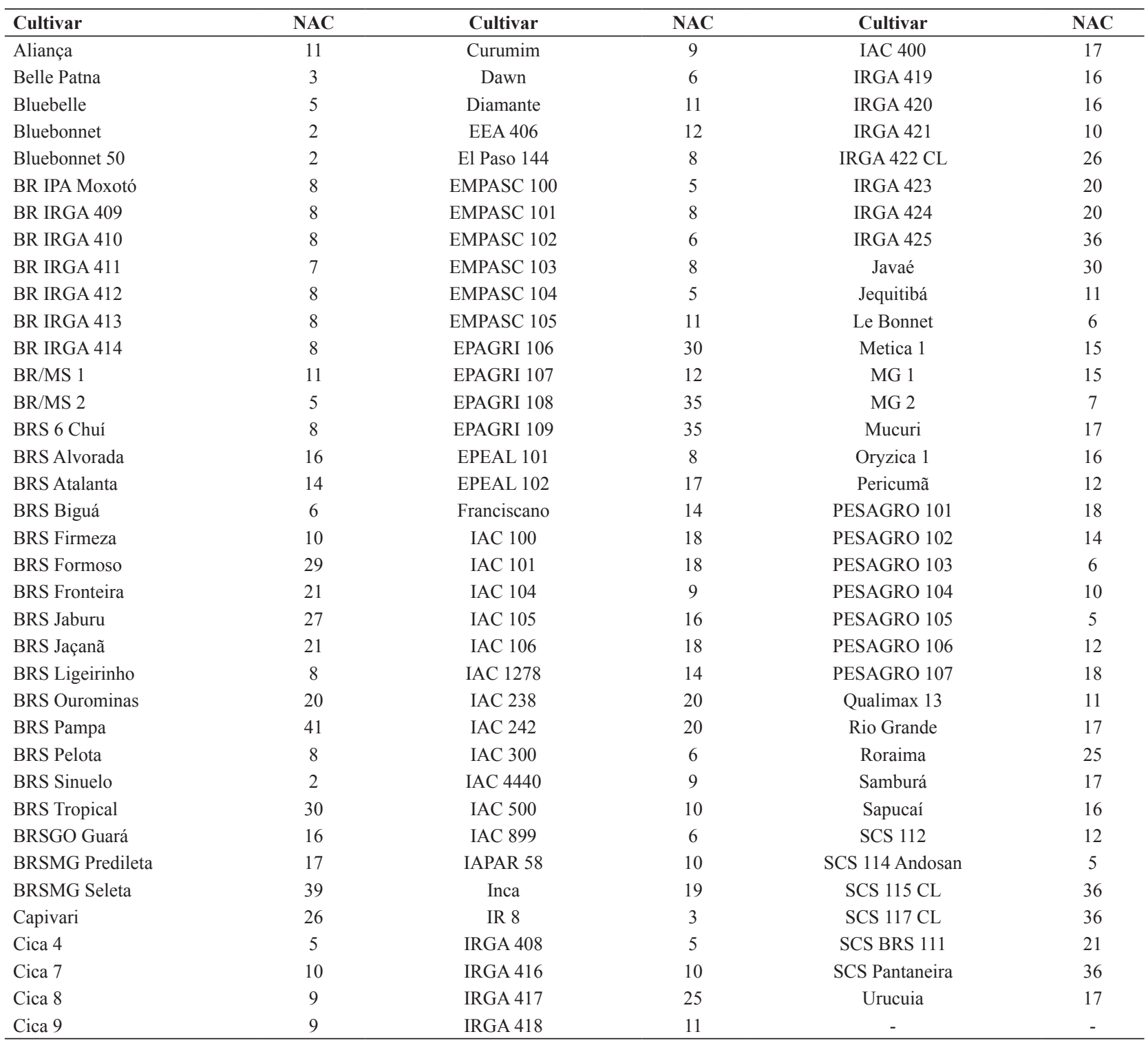


been reported. Genetic contributions of AS 3510 are also observed in the cultivars SCS $115 \mathrm{CL}$, SCS $117 \mathrm{CL}$ and BR IRGA 422 CL.

The greatest NAC are attributed to BRS Pampa (NAC $=$ 41) and BRSMG Seleta $(\mathrm{NAC}=39)$. Both of them have two sources of resistance to rice blast (Pyricularia grisea) coming from the ancestors Tetep and Tadukan (Rangel et al. 1996). According to Magalhães Júnior (2011), BRS Pampa has intermediate to moderate resistance to rice blast and according to Soares et al. (2004b), BRSMG Seleta is resistant.

The 17 cultivars released commercially in the period from 1965 to 1980 have a narrow genetic base, and they were developed from 32 ancestors (Table 3), with eight cultivars being introduced from other countries (Belle Patna, Bluebelle, Bluebonnet, Bluebonnet 50, Cica 4, Cica 7, Dawn and Le Bonnet). Eight of these ancestors represented approximately $70 \%$ of the genealogy, and Marong Paroc, Dee Geo Woo Gen, Cina and Latisail ancestors together contributed to $45 \%$ of the genealogy (Table 4 ). The narrowing of the genetic base in this period from 1965 to 1980 is more accentuated, for around $90 \%$ of the genes are represented by 15 ancestors, and the cultivars consist of an average of 1.88 ancestors (Table 3 ).

In the period of 1981-1990, twenty-five new ancestors were incorporated in the genetic base of the Brazilian irrigated rice cultivars. In numerical terms, there was no alteration of the genetic base, since approximately $70 \%$ of the gene pool originate from eight ancestors, just as in the previous period (Table 3). In the period of $1991-2000$ it began what was considered as an increase in the genetic base, since around $70 \%$ of the genealogy of the 36 cultivars released commercially in this period originate from 11 ancestors (Table 3). Nevertheless, just as in the previous period, a preference was seen for the use of more adapted genotypes in the development of the cultivars, since Dee Geo Woo Gen, Cina, Latisail and MCVA are responsible for around $50 \%$ of the gene pool. The genetic base with the greatest number of ancestors was observed for the 26 cultivars released commercially from 2001 to 2012. In this period, ninety-two ancestors were used, thirty-nine of them being new, and approximately $60 \%$ of the genetic base is represented by 14 ancestors, practically double the average of the previous periods (Table 3 ). The greatest values of ANAC (20.19) and NA/NC (3.53) are also attributed to this period, which highlight the cultivars broad genetic base.

In spite of the large number of ancestors, the genetic base of Brazilian upland rice cultivars is considered to be narrow, since around $70 \%$ of the gene pool studied is derived from 13 ancestors. Cuevas-Pérez et al. (1992) obtained similar results for irrigated rice cultivars recommended from 1971 to 1989 for the regions of Latin America and the Caribbean. Similar to the present study, it was observed that 14 ancestors represented $70 \%$ of the genetic base, and that Cina, Latisail and Dee Geo Woo Gen were the most used ancestors. Montalván et al. (1998) report a similar narrowing for upland rice cultivars released for commercial use from 1971 to 1993 ; it was observed that approximately $70 \%$ of the genetic base is derived from the Brazilian ancestors Dourado Precoce, Pérola and Pratão.

When ancestors with RGC of less than $2 \%$ are disregarded, the genetic base becomes even narrower, being restricted to ten ancestors, which represent $66 \%$ of the entire gene pool (Table 1). Rangel et al. (1996) report greater narrowing of the genetic base of irrigated rice cultivars recommended for Brazil in the 1992/93 crop season, also obtaining an effective size $\left(\mathrm{N}_{\mathrm{e}}\right)$ of ten ancestors, when considering only those with RGC above $2 \%$. The same ten ancestors contributed to $68 \%$ of the genes of the cultivars used in the period from 1980 to1992.

The average number of ancestors per cultivar (ANAC) was estimated at 14.37 (Table 3). This parameter should be used with restriction in the study of genetic base, since it does not represent the amplitude of contributions from parents for the cultivars. In addition, within each cultivar, the genetic contributions of the ancestors vary in magnitude, such as the cultivar IRGA 425, which, in spite of being

Table 3. Number of cultivars (NC), number of ancestors (NA), average number of ancestor per cultivar (ANAC), number of ancestors responsible for $60 \%, 70 \%, 80 \%$ and $90 \%$ of the genetic base (NAGB), number of new ancestors added to the genetic base for each reporting period and ratio between the number of ancestors and the number of cultivars $(\mathrm{NA} / \mathrm{NC})$ of Brazilian irrigated rice cultivars released on the commercial market in the period from 1965 to 2012

\begin{tabular}{|c|c|c|c|c|c|c|c|c|c|c|}
\hline \multirow{2}{*}{ Period } & \multirow{2}{*}{$\mathrm{NC}$} & \multirow{2}{*}{ NA } & \multirow{2}{*}{ ANAC } & \multicolumn{4}{|c|}{ NAGB (\%) } & \multirow{2}{*}{ NA/NC } & \multirow{2}{*}{$\begin{array}{c}\text { Previous } \\
\text { ancestors }\end{array}$} & \multirow{2}{*}{$\begin{array}{c}\text { New } \\
\text { ancestors }\end{array}$} \\
\hline & & & & 60 & 70 & 80 & 90 & & & \\
\hline $1965-1980$ & 17 & 32 & 5.88 & 6 & 8 & 11 & 15 & 1.88 & - & 32 \\
\hline $1981-1990$ & 31 & 43 & 10.87 & 6 & 8 & 13 & 20 & 1.39 & 18 & 25 \\
\hline $1991-2000$ & 36 & 59 & 17.27 & 7 & 11 & 16 & 25 & 1.64 & 32 & 27 \\
\hline $2001-2012$ & 26 & 92 & 20.19 & 14 & 19 & 26 & 38 & 3.53 & 53 & 39 \\
\hline $1965-2012$ & 110 & 123 & 14.37 & 8 & 13 & 23 & 43 & 1.12 & - & - \\
\hline
\end{tabular}


composed of 36 ancestors, $50 \%$ of its genes come from the ancestor IRGA 1598.

The ratio between the number of ancestors and the number of cultivars (NA/NC) was 1.12, and it is considered low, comparing with values of other studies in which the genetic base was considered narrow. Cuevas-Pérez et al. (1992) obtained a value of 1.25 for the irrigated rice cultivars recommended for Latin America and the Caribbean from 1971 to 1989, and Montalván et al. (1998) obtained a value of 1.29 for Brazilian upland rice cultivars. Therefore, the value of NA/NC obtained in this study may be one more indication of the narrow genetic base of Brazilian irrigated rice.

The low value of NA/NC is brought about by the use of the same ancestors in the composition of various cultivars due to the preference of breeding programs in using the most adapted genotypes as parents in different crossings.

In relation to the use of genotypes from breeding programs in crossings, Nass and Parteniani (2000) emphasize that wild accessions, or those that are not a result of breeding programs, have been left aside by breeders since the use of new sources of variability requires prior work for characterization and more selection cycles for obtaining superior genotypes.

The ancestor Dee Geo Woo Gen is involved in the formation of $89.19 \%$ of the cultivars evaluated. According to Soares et al. (2004a), this genotype, as well as I Geo Tze, is Chinese cultivar that bear a recessive allele which confers low height, and, exclusively in these cultivars, the dwarf allele does not affect the stretching out of spikelets and panicles. Therefore, the use of these ancestors seeks to obtain semi-dwarf size cultivars, a trait that is desirable for modern rice cultivars.

The ancestors Cina and Latisail were likewise used in $83.78 \%$ of the cultivars. The high frequency of these genotypes in the genealogy is due in part to the fact of being the genitors of Peta cultivar - which, for its part, is the female parent of IR 8, with Dee Geo Woo Gen being the male parent. Released by the IRRI in 1966, IR 8 has semi-dwarf height, insensitivity to photoperiod, high tillering and high yield. IR 8 is considered as the first cultivar of the Indica group, which is highly productive and adapted to tropical climates (Soares et al. 2004a). Since it aggregates various agronomic traits favorable to the climatic conditions of Brazil, IR 8 was widely used in the development of Brazilian cultivars.

The narrowing of the genetic base in the period from 1965 to 1980 is more accentuated, for around $90 \%$ of the genes are represented by 15 ancestors, and the cultivars consist of an average of 1.88 ancestors (Table 3 ). In the period from 1981 to $1990,70 \%$ of the gene pool came from
Table 4. Relative genetic contribution ( $\mathrm{RGC} \%$ ), accumulated genetic contribution (AGC\%) and frequency of the ancestors in the genealogy $(\mathrm{FAG} \%)$ of the principal ancestors of Brazilian cultivars of rice released on the commercial market in the four reporting periods (1965-1980, 19811990, 1991-2000, 2001-2012)

\begin{tabular}{|c|c|c|c|}
\hline Ancestors & RGC (\%) & AGC (\%) & FAG (\%) \\
\hline \multicolumn{4}{|l|}{ Period 1965-1980 } \\
\hline MarongParoc & 16.2799 & 16.2799 & 58.8235 \\
\hline Dee Geo Woo Gen & 12.5000 & 28.7799 & 52.9412 \\
\hline Cina & 8.5938 & 37.3736 & 52.9412 \\
\hline Latisail & 8.5938 & 45.9674 & 52.9412 \\
\hline Pa Chiam & 7.8699 & 53.8373 & 58.8235 \\
\hline MCVA & 6.2500 & 60.0873 & 41.1765 \\
\hline \multicolumn{4}{|l|}{ Period 1981-1990 } \\
\hline Dee Geo Woo Gen & 17.0961 & 17.0961 & 96.7742 \\
\hline Latisail & 15.0194 & 32.1155 & 90.3226 \\
\hline Cina & 14.9501 & 47.0656 & 90.3226 \\
\hline MCVA & 5.4435 & 52.5091 & 64.5161 \\
\hline I Geo Tze & 5.4435 & 57.9527 & 64.5161 \\
\hline Tetep & 4.9395 & 62.8922 & 32.2581 \\
\hline \multicolumn{4}{|l|}{ Period 1991-2000 } \\
\hline Dee Geo Woo Gen & 15.9901 & 15.9901 & 100.0000 \\
\hline Latisail & 15.1166 & 31.1067 & 94.4444 \\
\hline Cina & 14.8935 & 46.0003 & 94.4444 \\
\hline MCVA & 4.8665 & 50.8668 & 88.8889 \\
\hline I Geo Tze & 4.8665 & 55.7333 & 88.8889 \\
\hline KhaoDawk Mali 105 & 3.7272 & 59.4606 & 61.1111 \\
\hline MarongParoc & 3.1445 & 62.6051 & 97.2222 \\
\hline \multicolumn{4}{|l|}{ Period 2001-2012 } \\
\hline Dee Geo Woo Gen & 11.2208 & 11.2208 & 88.4615 \\
\hline Latsail & 9.4865 & 20.7072 & 84.6154 \\
\hline Cina & 9.3893 & 30.0965 & 84.6154 \\
\hline MarongParoc & 3.8840 & 33.9805 & 84.6154 \\
\hline KhaoDawk Mali 105 & 3.8105 & 37.791 & 50.0000 \\
\hline BRS Taim & 3.3654 & 41.1564 & 3.8462 \\
\hline MCVA & 3.0950 & 44.2514 & 73.0769 \\
\hline I Geo Tze & 3.0950 & 47.3463 & 73.0769 \\
\hline AS 3510 & 2.8846 & 50.2309 & 15.3846 \\
\hline Tadukan & 2.6433 & 52.8742 & 73.0769 \\
\hline IRGA 407 & 1.9231 & 54.7973 & 7.6923 \\
\hline 17719 & 1.9231 & 56.7204 & 3.8462 \\
\hline Arborio & 1.9231 & 58.6434 & 3.8462 \\
\hline IRGA 1598 & 1.9231 & 60.5665 & 3.8462 \\
\hline
\end{tabular}

eight ancestors, just like on the previous period. However, it can be considered that there was genetic narrowing, since the ancestors Dee Geo Woo Gen, Latisail, Cina and MCVA represented $52 \%$ of the total genealogy, and Dee Geo Woo Gen was the one that stood out (Table 4)

All the cultivars released commercially in the period from 1991 to 2000 have some degree of kinship, since $100 \%$ of them have genes from Dee Geo Woo Gen (Table 4). In the period from 2001 to 2012 it was observed some widening in genetic base for the 26 cultivars released 
commercially. In this period, 92 ancestors were used, 39 of them being new and approximately $60 \%$ of the genetic base is represented by 14 ancestors, practically double the average of the previous periods (Table 3 ). This may be due to disclosure of the genealogies and studies on the genetic base of Brazilian cultivars in the 1990's.

The greatest values of ANAC (20.19) and NA/NC (3.53) are also attributed to this period, which highlight the broad genetic base of the cultivars. Nevertheless, the genetic base may be considered as unbalanced, for only 38 ancestors represent around $90 \%$ of the genealogy, and the remaining 50 contribute to less than $10 \%$. Just as in most of the previous periods, Dee Geo Woo Gen, Cina and Latisail were the most used ancestors. This practice restricts the possibilities for recombination in breeding programs and increases the genetic uniformity of the nucleus and cytoplasm, which may result in vulnerability of the cultivars to biotic and abiotic stresses and restriction of gains from selection, especially for quantitative traits (Vello et al. 1988, Rangel et al. 1996, 2000).

Aiming at expanding the genetic base, Rangel et al. (1996) suggest some alternatives. One of them would be the crossing of divergent parents originating from other breeding programs for the desired agronomic traits. Another option would be the use of multiple crossings between accessions of exotic germplasm and non-kin elite genotypes, or genotypes with a small degree of kinship. A third strategy consists of using recurrent selection for composition of populations with a broad genetic base; nevertheless, the high cost of implementation of this method impedes its adoption in breeding programs (Canci et al. 1997).

The use of male-sterile lines may make the use of recurrent selection viable, since it reduces operational costs, and favors natural recombination (Coimbra et al. 2008). However, the use of male-sterility is restricted due to the complexity of handling and maintenance of the genotypes bearing the sterility genes.
Rangel et al. (1996) also indicate the use of wild rice species as another alternative for expansion of the genetic base. In this context, the use of $O$. glumaepatula in hybridizations with $O$. sativa is an efficient alternative for increasing the genetic base of rice, as well as providing the attainment of genotypes with high yield and desirable agronomic traits, which are able to be used as parents in new crosses (Cordeiro and Medeiros 2010b).

It may be seen that the narrow total genetic base of Brazilian irrigated rice cultivars is due to the fact that the genetic breeding programs for Brazilian rice began from a reduced number of genotypes, nearly all of them coming from other countries. Over the years, there was incorporation of new sources of variability, which contributed to expansion of the genetic base. This may have arisen from awareness on the part of breeders in regard to the risks of genetic base narrowing. Nevertheless, the use of new genotypes appraisable by genetic breeding and better utilization of currently available genetic resources are necessary since many of the ancestors of the genetic base of Brazilian irrigated rice are little used.

\section{CONCLUSIONS}

The genetic base of Brazilian irrigated rice cultivars in the period from 1965 to 2012 is narrow.

The narrowing of the genetic base is mainly brought about by the use of the same genotypes as parents of various crossing.

The genetic base of cultivars released commercially in the period from 2001 to 2012 is the broadest among the periods evaluated. Nevertheless, many of the ancestors used in this period contribute in small proportion to the genetic base.

\section{ACKNOWLEDGMENTS}

The authors thank CAPES (Coordination of Improvement of Higher Education Personnel) for financial support.

\section{Base genética das cultivares brasileiras de arroz irrigado}

Resumo - O presente trabalho teve por objetivo estimar a base genética de cultivares brasileiras de arroz irrigado liberadas
comercialmente no periodo de 1965 a 2012. As genealogias das cultivares foram obtidas com base em informações de folders
de divulgação de cultivares, sites de internet, livros de registros de cruzamentos e artigos científicos. Os seguintes fatores foram
calculados: contribuição genética relativa (RGC), contribuição genética acumulada (AGC), frequência (em porcentagem) de cada
ancestral na genealogia (FAG), número de ancestrais que constitui cada cultivar (NAC), número de ancestrais responsáveis por
$60 \%, 70 \%, 80 \%$ e $90 \%$ da base genética (NAGB) e número médio de ancestrais por cultivar (ANAC). As cultivares foram também
agrupadas baseando-se no periodo de lançamento (1965-1980, 1981-1990, 1991-2000 e 2001-2012); para cada agrupamento, os
fatores previamente citados também foram estimados. Um total de 110 cultivares foi estudado. Concluiu-se que a base genética das
cultivares brasileiras de arroz irrigado é estreita.

Palavras-chave: Oryza sativa, contribuição genética relativa, contribuição genética acumulada, genealogias, vulnerabilidade genética. 


\section{REFERENCES}

Canci PC, Barbosa Neto JF and Carvalho FIF (1997) Implementação da seleção recorrente no melhoramento de plantas autógamas através da macho-esterilidade. Ciência Rural 27: 505-512.

CEPA (2011) Arroz - safra 2010/11, produção e mercado mundial, EPAGRI. Available at <http://cepa.epagri.sc.gov.br/Publicacoes/ Sintese_2011/Arroz\%20sintese\%202011.pdf>. Accessed in October, 2012.

CIAT (2005) CIAT rice varieties released in Latin America and the Caribbean. Available at <http://www.ciat.cgiar.org/ourprograms/ Agrobiodiversity/rice/Documents/rice_varieties_lac.pdf $>$. Accessed on 20 April 2012.

Châteal M and Guimarães EP (2002) International partnership for rice improvement in Latin America: CIRAD, a case study. Crop Breeding and Applied Biotechnology 2: 639-648.

Coimbra JLM, Bertoldo JG and Vale NM (2008) Uso da macho-esterilidade no melhoramento de híbridos comerciais em arroz. Revista de Ciências Agroveterinárias 7: 61-74.

Cordeiro ACC (2008) Métodos de melhoramento genético de arroz irrigado. EMBRAPA Roraima, Boa Vista, 64p.

Cordeiro ACC and Medeiros RD (2010a) BRS Jaçanã e BRS Tropical: cultivares de arroz irrigado para os sistemas de produção de arroz em várzea de Roraima. Revista Agro@ambiente on-line 4: 67-73.

Cordeiro ACC and Medeiros RD (2010b) Desempenho produtivo de genótipos de arroz oriundos de hibridação interespecífica entre Oryza sativa e Oryza glumaepatula, em várzea de Roraima. Amazônia, Ciência e Desenvolvimento 5: 1-10.

Cuevas-Pérez FE, Guimarães EP, Berrio LE and Gonzáles DI (1992) Genetic base of irrigated rice in Latin American and the Caribbean, 1971 to 1989. Crop Science 32: 1054-1059.

Cui Z, Carter Junior TE and Burton JW (2000) Genetic base of 651 Chinese soybean cultivars released during 1923 to 1995 . Crop Science 40: 1780-1793.

Cutrim VA and Rangel PHN (2002) BRS Jaburu - Irrigated rice cultivar for the states of Goiás and Tocantins. Crop Breeding and Applied Biotechnology 2: 479-480.

Delannay DM, Rodgers DM and Palmer RG (1983) Relative genetic contribution among ancestral lines to North American soybean cultivars. Crop Science 23: 944-949.

Dilday RH (1990) Contribution of ancestral lines in the development of new cultivars of rice. Crop Science 30: 905-911.

IRRI (1985) Parentage of IRRI of crosses IR 1-IR 50,000. IRRI, Manila, 508p.

IRRI (1998) INGER-derived rice varieties directly released in various countries. IRRI, Los Baños, 37p.

Magalhães Júnior AM (2011) BRS Pampa: cultivar de arroz agulhinha incrementa produtividade no Sul. Available at $<$ http://www.snt. embrapa.br/publico/usuarios/produtos/234-Anexo3.pdf>. Accessed in December, 2012.

Magalhães Júnior AM, Fagundes PRR, Franco D, Andres A, Rangel PHN, Moraes OP, Moura Neto F and Severo ACM (2010) BRS Sinuelo CL: cultivar de arroz irrigado para o sistema Clearfield ${ }^{\circledR}$. Embrapa Clima Temperado, Pelotas, $8 \mathrm{p}$.

Montalván R, Destro D, Silva EF and Montaño DC (1998) Genetic base of Brazilian upland rice cultivars. Journal of Genetics \& Breeding 53: 203-209.

Morais OP, Castro EM, Souza NRG, Prabhu AS, Bassinelli PZ and Fonseca JR (2004) Cultivares de arroz de terras altas para o Mato Grosso. Embrapa Arroz e Feijão, Santo Antônio de Goiás, 8p. (Circular Técnica 68)

Morais OP and Rangel PHN (1997) Melhoramento de arroz no Brasil. In: simpósio sobre atualização em genética e melhoramento de plantas. UFLA, Lavras, p. 147-166.

Nass LL and Paterniani E (2000) Pre-breeding: a link between genetic resources and maize breeding. Scientia Agrícola 57: 581-587.

Rangel PHN, Bondani C, Morais OP, Schiocchet MA, Borba TCO, Rangel PN, Brondani RPV, Yokoyama S, Bacha RE and Ishy T (2007) Establishment of the irrigated rice cultivar SCSBRS Tio Taka by recurrent selection. Crop Breeding and Applied Biotechnology 7: 103-110.

Rangel PHN, Guimarães EP and Neves PCF (1996) Base genética das cultivares de arroz (Oryza sativa L.) irrigado do Brasil. Pesquisa Agropecuária Brasileira 31: 349-357.

Rangel PHN, Pereira JA, Morais OP, Guimarães EP and Yokokura T (2000) Ganhos na produtividade de grãos pelo melhoramento genético do arroz irrigado no meio norte do Brasil. Pesquisa Agropecuária Brasileira 35: 1595-1604.

Silva, EF, Montalván R and Ando A (1999) Genealogia dos cultivares brasileiros de arroz-de-sequeiro. Bragantia 58: 281-286.

Soares PC, Melo PGS, Melo LC and Soares AA (2005) Genetic gain in an improvement program of irrigated rice in Minas Gerais. Crop Breeding and Applied Biotechnology 5: 142-148.

Soares AA, Soares PC, Castro EM, Morais OP, Rangel PHN and Reis MS (2004a) Melhoramento genético de arroz em Minas Gerais. Informe Agropecuário 25: 19-23.

Soares PC, Soares AA, Morais OP, Castro EM, Rangel PHN, Cornélio VMA and Souza MA (2004b) Cultivares de arroz de terras altas e de várzeas recomendadas para Minas Gerais. Informe Agropecuário 25: $25-34$.

Vello NA, Hiromoto DM and AzevedoFilho AJBV (1988) Coefficient of parentage and breeding of Brazilian soybean germplasm. Revista Brasileira de Genética 11: 679-697.

Viegas GP, Germek EB and Miranda HS (1945) Contribuição para a melhoria da rizicultura no Estado de São Paulo. Bragantia 5: 187-196. 